Article

\title{
Project-Based Learning in a Transinstitutional Research Setting: Case Study on the Development of Sustainable Food Products
}

\author{
Hartmut Derler ${ }^{1,2, *}$, Simon Berner ${ }^{1}$, Daniela Grach ${ }^{3}$, Alfred Posch ${ }^{2}\left(\mathbb{D}\right.$ and Ulrike Seebacher ${ }^{1}$ \\ 1 Institute of Applied Production Sciences, Sustainable Food Management, University of Applied Sciences FH \\ JOANNEUM, Eggenberger Allee 11, 8020 Graz, Austria; simon.berner@fh-joanneum.at (S.B.); \\ ulrike.seebacher@fh-joanneum.at (U.S.) \\ 2 Institute of Systems Sciences, Innovation and Sustainability Research, University of Graz, Merangasse 18/1, \\ 8010 Graz, Austria; alfred.posch@uni-graz.at \\ 3 Department of Dietetics and Nutrition, University of Applied Sciences FH JOANNEUM, \\ Kaiser-Franz-Josef-Strasse 24, 8344 Bad Gleichenberg, Austria; daniela.grach@fh-joanneum.at \\ * Correspondence: hartmut.derler@edu.uni-graz.at
}

Received: 25 November 2019; Accepted: 19 December 2019; Published: 26 December 2019

\begin{abstract}
Project-based learning (PBL) has been thoroughly integrated in university sustainable development curricula, but has not been well-established in curricula used at pre-university educational levels. Integrating real-world settings into the teaching of secondary school students can help to promote problem-solving skills and competencies at younger ages, which is a crucial task in sustainability education. Therefore, in this article we describe the results of a case study on the development of sustainable food products that involved a university and two secondary schools in Austria. The methods used in this case study were drawn from the transdisciplinary case study (TCS) and the PBL literature. Data were collected by carrying out participatory research methods such as photovoice, focus group discussions, food diaries, student evaluations, and surveys. We divided the study design into three phases: (1) exploration, (2) product ideation, and (3) product prototyping and optimisation. The case study illustrates that the use of PBL research approaches by students at different levels of education provides promising results, if the research process is clearly structured and managed. When a demand for learning is encountered by students, secondary school teachers and university researchers must provide the students with additional sources of information. The establishment and management of a transinstitutional research setting is a promising, yet time-consuming endeavour.
\end{abstract}

Keywords: education for sustainable development; project-based learning; sustainable food products; secondary-school students

\section{Introduction}

Scholars widely agree that the most pressing problems of modern society can only be addressed by merging concepts and methods from different disciplines. In addition to these interdisciplinary research approaches, scholars also consider transdisciplinarity (TD) to be a promising research paradigm that supports the movement of transformational processes towards sustainable development [1,2]. TD is considered as a research process that involves interactions between scholars and practitioners [3] and thus goes beyond disciplines [4]. According to Ramadier (2004, p. 424) [5], what differentiates TD from pluri- and interdisciplinarity is that it "concerns the articulation between disciplines, rather than their relations." Furthermore, TD differentiates from mono- and interdisciplinarity in that knowledge and values from society are integrated into the production of knowledge [6]. 
TD gained momentum due to the view that addressing the world's most pressing problems (e.g., biodiversity loss, global warming, social challenges) can only be successful through enabling mutual learning processes between science and society [7]. TD has consequently been included in many sustainable development curricula, and has become popular within the Educational for Sustainable Development (ESD) framework [8-11]. In part, the popularity of TD stems from the fact that integrating real-world problems into teaching enhances the students' ability to systematically understand interlinked social, economic, and environmental factors, encouraging them to use different modes of thinking [9]. Here, learning processes serve as conceptual links between research and teaching, allowing the identification of innovative solutions that support a sustainable future development $[3,12]$. Furthermore, learning in TD approaches focusses on the mutual exchange rather than traditional, individualized learning of case agents [6], and the co-construction of knowledge and participation are important concepts therein [13]. Participatory research approaches have also gained an increasing amount of recognition at the European level as part of the Responsible Research and Innovation (RRI) framework, because they are considered to democratize knowledge production and transform scientific research from a closed into an open activity [14].

In food and nutrition studies, an increasing amount of attention has been paid to approaches that can be taken to enhance young people's food knowledge and competencies, helping them make well-informed food decisions that lead to healthier food practices. In this respect, the term food literacy emerged and is used to "describe the everyday practicalities associated with healthy eating" [15] (p. 50). As such, professionals in the food industry consider this concept as promising, using it to enhance the students' understanding of the food system and related issues [16]. Generally, food literacy refers to an enhancement of knowledge about basic commodities, such as how to prepare food, judge food quality, apply basic principles of food hygiene and understand personal needs to attain a balanced food intake. Young people have experienced positive changes as a result of food literacy interventions in several food literacy programs [17]. However, the scope of these programmes has been relatively narrow; young people were taught simple food-making skills (e.g., in cooking classes) [18], but the education did not include aspects of food technology, food engineering or sustainability as core elements [19]. When combined with sustainability education, however, food technology education (FTE) can help students develop an enhanced understanding of the underlying scientific concepts and broaden their knowledge of food-related issues, including the social and ecological consequences of food usage. Thus, combining FTE and sustainability education can help students better prepare themselves for citizenship and employment [20].

Our analysis of the relevant literature revealed two gaps, which are addressed in this article. First, while TD is well-established in academic settings, the concept has received less attention on pre-university educational levels. Second, food literacy approaches have tended to focus on food-making skills; this case study broadens the food literacy concept by associating it with sustainability education and FTE through project-based learning (PBL) as a didactic framework.

In this article, we describe the results of a research approach taken to enhance food literacy amongst secondary school students. The research was carried out to determine how food technology and sustainability education could be promoted amongst secondary school students. The first objective of the research was to explore the students' food decisions by applying participatory research methods. The second objective, based on the initial findings, was to identify and produce sustainable food products by students for students. In Section 2, we outline the conceptual foundations of the case study. In Section 3, we present the results of the data collection. We then compare these results to those appearing in the PBL and transdisciplinary case study (TCS) literature. In Section 4, we state PBL findings and lessons in a transeducational research setting. A final summary and conclusion is provided in Section 5. 


\section{Case Study Background}

\subsection{Conceptual Background}

In our case study, the applied TD research approach included the following three dimensions: (1) the integration of complex and multidimensional real-world problems (i.e., in our case study, the development of sustainable food products); (2) the involvement of interactions between scholars and practitioners, therefore transcending " [ ... ] academic boundaries to incorporate collaboration and mutual learning" (i.e., in our case study, the collaboration among students, teachers, and researchers); and, (3) the choice of a method that iteratively reflects a specific problem and its context from multi-perspectives (i.e., transdisciplinary case studies (TCS) [21] (p. 255)). In the mid-2000s, TCS were developed by the Natural and Social Sciences Interface in Switzerland as a research methodology for teaching and research on complex social, ecological and economic problems [22]. This methodology is based on the idea "[ ... ] of educating students in real-world settings" [23] (p. 432). Since that time, it has been integrated into several curricula of Sustainable Development (SD) study programs [11].

TCS combines three components, namely, (1) case studies, (2) TD, and (3) sustainable development [24], and draws on PBL as a didactic framework [25]. While researchers have more frequently used case studies to connect problems with scientific theories, TCS differ from simple case studies in that (a) the design types are embedded in single cases rather than in holistic and multiple cases, (b) the researchers using TCS are motivated to conduct research for intrinsic rather than instrumental reasons, (c) the epistemological status is descriptive rather than exploratory or explanatory, (d) the case formats are unstructured rather than highly structured, (e) the processes of synthesis are driven by formative methodology rather than by informal empathic intuition, and (f) the scientific typology is transdisciplinary rather than monodisciplinary or interdisciplinary [24].

One goal of carrying out TCS is to use unique modes of sustainability learning. Sustainability learning can be understood "[ ... ] as the learning of individuals and human systems such as groups, organisations, and human societies, which aims to achieve and facilitate sustainable development" [26] (p. 2877). In this regard, sustainability learning is distinct from social learning, because not all outcomes of the latter support long-term sustainability [27].

The prerequisite choice of an adequate problem drives sustainability learning [25]. The problem must be both ill-defined and allow interactions between learning agents, such that a demand for learning is triggered. In such situations, TCS can elicit the so-called 'pull-concept for mutual learning' [12]. While linear learning concepts (i.e., learning in mono- and interdisciplinary settings) are based on the assumption that learning takes place at three hierarchical levels (i.e., knowing, understanding, applying), the pull-concept for mutual learning is based on the assumption that learning (i.e., learning in TD settings) occurs as a result of an ill-defined problem. Thus, "[...] a situation arises where the application of as yet incomplete knowledge takes place," such that "[ ... ] students become intrinsically motivated and themselves wish to gather knowledge as a tool for problem solving [ ... ]" [12] (p. 283-284). As a consequence, a circular (Figure 1a) rather than a linear relationship (Figure 1b) exists among knowing, understanding, and applying. 


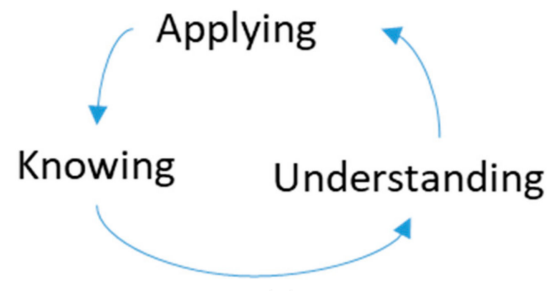

(a)

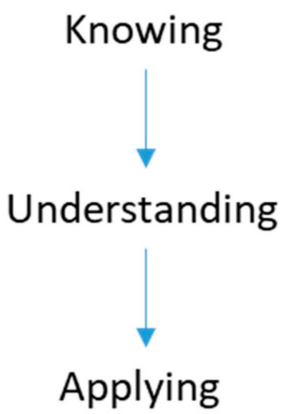

(b)

Figure 1. Relationships exist among knowing, understanding, and applying: (a) The pull-concept for mutual learning; (b) linear learning concepts.

Consequently, the students—not the teachers-play the most active roles in such research settings. Nevertheless, the teachers are responsible for providing an organisational framework that includes milestones, outlines, and contents acceptable to all case agents, so that they want to participate throughout the project [12]. As a result, in such a learning setting, the students change their roles from knowledge receiver to knowledge producer, and teachers from knowledge deliverer to interactive learning designers [28]. In addition, TD learning is distinct from mono- and interdisciplinary learning (ID learning) because mono- and ID learning build on a discipline or a mixture of disciplines to solve problems, whereas TD learning " $[. .$. ] facilitates collaborative learning through a shared conceptual framework" [28] (p. 84). In our case study, the collaborative learning took place along the students' projects, and TCS served as the shared conceptual framework.

In general, three principles drive learning in project-based case studies: (1) The learning process is centered around a focal point, represented by a case or problem that the students try to define and solve; (2) cooperative learning takes place among the students and with people outside academia; (3) and the students plan, conduct, and communicate the results of their projects as a team, whereby group processes and their management are vital $[23,25,29]$.

\subsection{Case Study Design}

The aim of this case study was to enhance competencies related to food, food technology, and sustainability among secondary school students in Austria. Three observations gave rise to the study. First, many adolescents in Austria do not follow national dietary recommendations, and the prevalence of obesity among 11- to 15-year-old adolescents is high (15\%-20\%) [30]. Second, studies have not been carried out to determine when adolescents begin to make their own food decisions. Third, interdisciplinary, educated employers in the food industry need to critically examine the food system they work in, so they can face the challenge of feeding nine billion people by 2050 [31].

The study involved 117 secondary school students aged 15 to 19 years. Fifty-six students attended a nutrition and agriculture school (School A), and 63 students attended a polytechnical school (School B). The research was embedded in two subjects taught at the two schools (i.e., project management at School A; ethics at School B) and was carried out over four semesters from September 2017 to July 2019. The research team consisted of researchers from different backgrounds (i.e., two sustainability researchers, three nutrition researchers, three food technology researchers, and three teachers (two from School A, one from School B)).

Based on the three principles of PBL mentioned in 2.1, we assigned the students a project task to develop sustainable food products for their peer group. Therefore, they formed groups, and the researchers and teachers served as the project facilitators. The project management was supported by the open-source e-portfolio management system Mahara [32]. During the case study, the schools had different thematic foci. While both schools contributed equally during phases one and two, only School 
A was involved in phase three of the project, since only this school had access to a functional kitchen and sufficient time resources for the students to develop their food products.

At the beginning of the study, a research coordination team (RCT) was introduced. The RCT consisted of two university researchers, two secondary school teachers, and two students. During the regularly scheduled RCT meetings, participants discussed milestones and planned activities and exchanged feedback about past collaboration. Thus, the RCT served as an instrument to encourage creative exchange among the case agents. It also helped them apply their perspectives to planned activities and establish a mutual understanding of the research goals, which is a crucial aspect in TD research projects [1].

Another important issue in TD is the research progress evaluation process [33-35]. Thus, the evaluation process was initiated once research commenced. During the first plenary meeting, we gathered oral feedback from the students about conducted workshops. The evaluation process included informal discussions and feedback meetings at the end of each semester with the students, teachers, and researchers. In general, the research process encompassed three phases: (1) exploration, (2) product ideation, (3) product prototyping and optimisation (Figure 2). The research design also was based on design thinking, a well-established method in PBL [36] that is commonly used to develop food product innovations [37]. A design thinking process has three "spaces": inspiration, ideation, and implementation. The first space is constituted by the identification and analysis of a problem; the second involves a process of synthesis, during which the analysed problem is distilled into ideas; and the third includes the prototyping and optimisation of a product or service [38]. The phases, the applied methods, and the didactic approaches are described below.

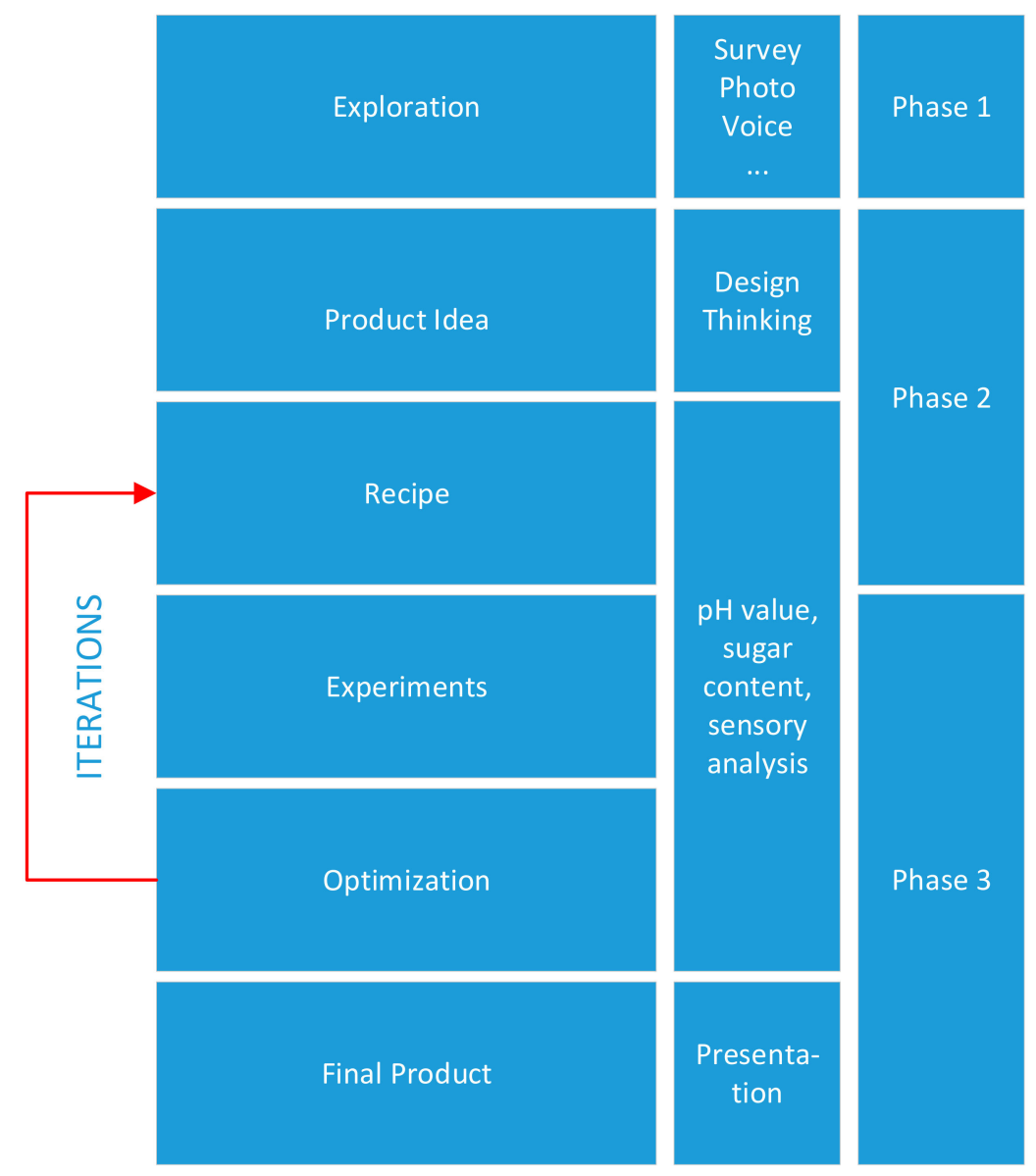

Figure 2. The applied product development process. 


\subsubsection{Phase One: Exploration}

The first phase started with a kickoff meeting, during which several thematic workshops were conducted. In one workshop, the project milestones, methods, and contents were presented and discussed. In another workshop, we introduced the students to Belasco's food triangle [39], which served as heuristic to explain how food choices are made. In principle, this triangle indicates that food choices are influenced by interactions among the three dimensions of identity, convenience, and responsibility. At this time, we asked the students to prepare a menu for themselves and three fictitious persons who each had specific food demands (i.e., one who was a vegetarian, one who was dieting, and one who was an organic milk farmer). The students had to choose an attractive menu that considered the persons' food preferences and describe why they chose this menu. It was necessary to establish a common language, as a crucial step in TD research studies [2]. Therefore, we introduced the students to basic scientific terms such as research question, hypothesis, scientific methods, data collection, documentation, and assessment.

After the kickoff meeting, we gathered data on the students' food consumption behaviour and perceptions. An online survey was sent out, which included questions about the students' (a) food preferences, (b) knowledge about nutrition and food technologies, and (c) dietary habits. These questions were taken from a questionnaire used to assess the health behaviour in school-aged children [40].

Up until this point in the study, research on, rather than by and with, the students was conducted. Therefore, we integrated the students into the data collection process by the means of photovoice and food diaries. Photovoice is a participatory action research method that encourages participants to take photographs and reflect on their specific contexts in focus group discussions [41]. Photovoice was chosen because it has been successfully applied to young people to explore several food-related domains such as health, food literacy, and food justice [18,42,43].

Initially, the students took photos that depicted positive and negative food consumption situations they encountered daily and commented briefly on them (Figure 3). Subsequently, the photos served as stimuli to initiate the focus group discussions on the students' food consumption decisions. Eight focus group discussions that lasted between 35 and 45 min were conducted. A broad spectrum of food topics were discussed, including students' emotions and perceptions towards their food consumption decisions. In addition, over the course of a week, the students gathered data on their food consumption decisions with food diaries (i.e., type of food, quantities, time of day). The students also took notes on different contexts, such as why they chose their meals and whether they took their meals alone or in company.

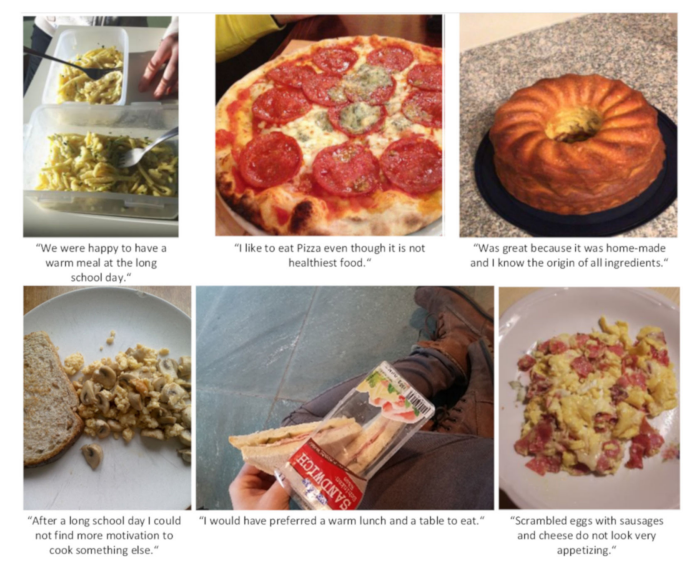

Figure 3. Sample photos and comments made by the students.

\subsubsection{Phase Two: Product Ideation}

The second phase (i.e., second semester) started with a plenary meeting, in which study participants presented and discussed the obtained data from phase one. The researchers presented results of 
the survey and focus group discussions, and the students presented results from their food diaries. The group drew conclusions on the students' eating habits, which were summarised on flipcharts and in student protocols. The goal of the second phase was to create food product ideas and translate results from the exploration phase into specifications for the product ideas. The students identified food product ideas with the help of personas. A persona is a fictitious individual in design thinking that represents a typical user, which is used to extrapolate from the persona to scenarios of use [44]. In small groups, the students wrote down information about a typical food consumption day, including personal attributes and how these affected their personas' food consumption decisions (Figure 4). This process helped them identify food product ideas that matched their personas' needs. After the students voted on the best ideas, five food product ideas entered the third phase. Subsequently, the students filled out product specification sheets (PSS) that included the categories youth-specific, technological, ecologic, social, economic, and health (Table 1).

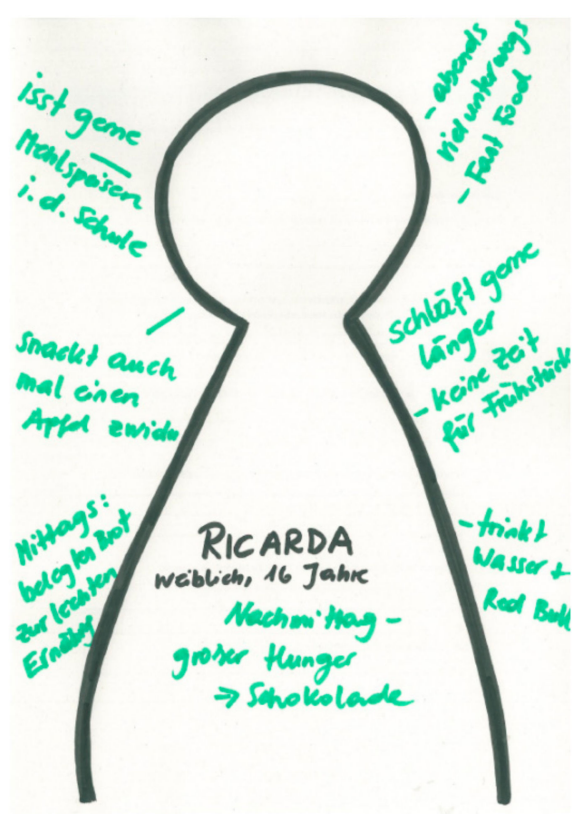

Figure 4. Sample persona and personal attributes of Ricarda, a 16-year-old female student. 
Table 1. Sample PSS with respective categories.

\begin{tabular}{|c|c|c|}
\hline Target Group Specific & Why Relevant? & When Met? \\
\hline Easily consumable & Fast energy provision & $\begin{array}{l}\text { When one can eat it in school } \\
\text { breaks }\end{array}$ \\
\hline$\cdots$ & & $\cdots$ \\
\hline Health-Related & Why Relevant? & When Met? \\
\hline $\begin{array}{l}\text { Reduced salt content } \\
\text { Avoid meat }\end{array}$ & Blood pressure & $\begin{array}{l}\text { When salt content is smaller than } \\
\ldots\end{array}$ \\
\hline$\cdots$ & $\cdots$ & $\cdots$ \\
\hline Ecologic & Why Relevant? & When Met? \\
\hline Organic ingredients & Biodiversity, nature conservation & All ingredients have organic origin \\
\hline$\ldots$ & $\cdots$ & $\cdots$ \\
\hline Economic & Why Relevant? & When Met? \\
\hline Costs & Limited budget & $100 \mathrm{~g}$ cost less than... \\
\hline$\cdots$ & $\ldots$ & $\ldots$ \\
\hline Social & Why Relevant? & When Met? \\
\hline Regional products & Strengthen local economies & $\begin{array}{l}\text { All ingredients stem from local } \\
\text { farmers }\end{array}$ \\
\hline$\cdots$ & $\cdots$ & $\cdots$ \\
\hline Technological & Why Relevant? & When Met? \\
\hline $\begin{array}{l}\text { First process step: } \\
\text { cleaning, cutting } \ldots \\
\text { Second process step: }\end{array}$ & Cleaning/contaminants & $\begin{array}{l}\text { When it's prepared for second } \\
\text { process step }\end{array}$ \\
\hline $\begin{array}{l}\text { cooking, steaming, roasting, } \\
\text { grilling }\end{array}$ & Process it for conservation, etc. & When it's cooked \\
\hline $\begin{array}{c}\text { Third process step: } \\
\text { cooling, drying, packaging, } \\
\text { storage }\end{array}$ & To enable storage & $\begin{array}{l}\text { When product's shelf life is } \\
\text { increased }\end{array}$ \\
\hline
\end{tabular}

\subsubsection{Phase Three: Product Prototyping and Optimization}

At the beginning of phase three (i.e., the third and fourth semester), we trained the students to conduct basic food analytical experiments and taught them sensory analysis methods. After the first prototypes had been developed, the students conducted physical, chemical, and sensory experiments to optimize their products with respect to specific parameters (i.e., relative tenderness, sugar content, water content, $\mathrm{pH}$ value). The students also conducted shelf-life tests by conducting pasteurisation and sensory tests.

A central element of the product development process was the documentation of the learning process. Therefore, the students wrote laboratory protocols, documenting the materials and methods used, product recipes, goals, results, and open questions resulting from the experiments. During meetings with the researchers, the students discussed obstacles that occurred in the experiments and their implications for the product development. Thus, these meetings helped the students to optimise their food products. In addition, the students checked whether their current prototype versions were in line with their defined PSS throughout this process (Table 1). This optimisation process was iterated three times. Thus, the optimisation took place in iterative steps, as denoted by the red arrow in Figure 2. The final products were presented in a public event at the end of the research project, and acceptance tests were conducted. The results of the data collection are shown below.

\section{Results}

The survey results and food diaries revealed that most students in both schools did not comply with national nutritional recommendations. For instance, almost half of the students indicated that 
they eat meat more than three times per week. Only ten percent of the students complied with the daily recommendations for vegetable and fruit consumption, and nearly two-thirds of the students consumed fast food at least once a week. A closer examination of the data revealed that the students from School A ate vegetables and fruits more frequently than the students from School B, whereas the students from School B ate more meat. Overall, the survey results showed that students from School A had slightly healthier eating habits. Concerning their food preferences, students from both school types indicated that the product qualities of taste, health, animal welfare, and the appearance were important to them. We observed differences between school types regarding the food qualities seasonal, local, and fair prices. The students from School A indicated preferences for higher food qualities than the students from School B. The food qualities of vegetarianism and veganism were unimportant to students from both school types. The students from School A performed better on questions about nutrition and food technologies.

Nearly 200 photos were documented as part of the photovoice method. The photos and their associated comments (e.g., "I like to eat Pizza even though it is not the healthiest food," Figure 3) served as inputs for the eight focus group discussions. The discussions helped participants gain a mutual understanding about the students' food consumption decisions, food preferences, and underlying values. For instance, the students commented that they had little time to eat during school, which significantly influenced their food consumption decisions, causing them to favour snacks and fast food. Many male students seemed to be concerned with high protein intake, because they were doing sports (i.e., weight training), and consumed protein-rich products to support muscle growth or preferred to eat meat-based products rather than vegetarian alternatives for organoleptic reasons. Although the students stated that they consumed fast food frequently, the discussions revealed that homemade, regional, and seasonal food were important to them. In addition, sustainability topics such as products from organic cultivation, fair wages, and animal ethics were addressed as central themes.

One critical moment of the project was the point at which the results from the exploration phase were integrated into the product development, which was approached by means of a design-thinking workshop and the PSS. In the workshop, the students contributed food product ideas for each persona, which were linked to the persona's personal attributes (e.g., 'enjoys eating snacks,' 'drinks water and energy drinks,' see Figure 4). For instance, one persona was described as an individual who was always hungry at school, because he or she practiced sports regularly and was currently experiencing a growth spurt. As a result, the students came up with the product idea of 'energy-bites,' a small praline rich in energy and fibre. A list of ten product ideas was gathered. After votes were cast, the study participants decided that the five product ideas-energy bites, cheese chips, smoothie, cereal bars, and pasta muffins-would be transformed into real products.

Furthermore, the study participants presented and discussed the results of the exploration phase in a plenary meeting. With the assistance of the researchers, the students defined specifications for six categories, and a detailed PSS was created for each product. For instance, they defined that their final product should fulfil the health criterion 'reduced salt content' and that the ingredients should come from local farmers (Table 1). During the product development process, they checked whether or not the current version of the product was in accordance with their defined specifications.

From this point onward, the students developed and optimised their food products by carrying out a series of experiments. Below, we describe the main findings of this project, and their implications.

\section{Discussion}

In this case study, the students worked on the project to develop sustainable food products. Thus, a real-life scenario was established that simulated the professional environment of food product engineers. During the first phase, they explored their food consumption habit by taking participatory and creativity-driven approaches that include photovoice, focus group discussions, food diaries, and elements of design thinking. These methods were chosen because they are useful when the research goal of a research is to collect narratives about the everyday food practices of adolescents [45]. 
In all phases of the case study, the students were not provided with an a priori solution regarding the appearance of their food products. Instead, we encouraged them to engage in repeated cycles of planning, action, observation, and reflection [46], with the researchers and teachers serving as project facilitators and process guides. Such periods of reflection support experiential learning processes and enhance the students' understanding of sustainable food systems [47]. Consequently, this self-directed learning approach resulted in a circular, rather than a linear, learning process (Figure 1).

The key drivers of this process, which both generated a demand for learning and constituted the learning process, were the PSS and the experiments. This will be illustrated by two examples. Over the course of the product prototyping, the students checked whether their prototype versions matched the PSS. One team produced a berry smoothie, which had a highly positive sensory test result. However, when they examined whether their prototype was in line with its respective specifications, they found that the specifications 'local food ingredients' and 'low costs' were not met, because most berries were locally available only in July, and their costs were too high. Thus, the students identified a conflict between the ecological and economic dimensions. Another team that developed cheese-flavoured chips experienced a similar issue. The student team initially planned to produce chips via a thermic treatment process (i.e., grating the cheese onto the chips and baking them in the oven), then to add seasonings such as herbs and spices. However, this version turned out to be too high in fat and too salty, and thus failed to meet the health specification. Consequently, both teams attempted to find solutions to these problems. Together with the teachers and the researchers, they discussed alternative approaches they could use to make their food products, and iteratively changed their product process based on the provided feedback.

In the first example, an apple-pear-yogurt smoothie was chosen because the ingredients were locally available during the whole year; at the same time, this version of the smoothie was cheaper than the former version. In the second example, the students suggested the idea to produce a dough that consisted of flour, potato starch, cheese, and seasonings (i.e., rosemary, caraway seeds). The students produced batches with different organic meal types (i.e., rye, spelt, wheat, whole grain meal), meal-to-starch ratios, and types of cheese. In this way, the fat and salt contents could be reduced, leading to a healthier product. After each trial, the students checked their current solutions against the respective PSS to create an acceptable product.

Thus, the use of the PSS categories helped the students understand that designing sustainable food products involves making complex decisions, especially when several dimensions of sustainability need to be considered simultaneously. When they checked the different specifications of their prototypes, they found that it was not always possible to match all categories and that the results in these categories could sometimes conflict.

During the experiments, two crucial aspects that enabled deeper learning processes were documentation and result interpretation. The students referred to their laboratory protocols while discussing the obstacles they encountered during the tests with the researchers. At first, the documentation seemed less important to the students. However, the longer the project lasted, the more care they took to properly document their activities. For instance, students who lost a protocol, which included lessons learnt from the past experiment, could not build on these results. Furthermore, students learned that results obtained from unstructured experiments were unreliable, forcing them to repeat these experiments to achieve repeatable results that could be used for optimisation of the production process. In this sense, the students engaged in learning cycles that then allowed them to optimise their food products (Figure 2).

University researchers should be aware of certain aspects when they apply a PBL research setting in secondary schools. For instance, researchers must provide a clear introduction to the topic and explain the basic concepts before addressing the respective projects. Furthermore, PBL generates a demand for learning, such that the students want to attend further classes and, therefore, learn new methods and competencies [48]. However, secondary school students usually cannot select specific 
subjects during a semester or in the next semester. Therefore, the researcher needs to provide additional information in the form of thematic workshops and motivate the students to work on their projects.

Planning and managing a case study that involves different school types also requires a significant time investment. For instance, to set up plenary meetings, one must identify dates that fit the timetables of both schools. For this reason, group meetings and personal exchanges among the students from both school types took place three times. The first took place at the beginning of the case study, and the other two at the end of each project year. Because only School A was involved in the production and optimisation of the food products (due to the presence of a functional kitchen in this school), School B only played a minor role during the third project phase.

To encourage learning, researchers must define a suitable project that is ill-defined, in the sense that the result of the project remains open-ended. However, a project goal needs to be clearly stated, and the number of abstract theories introduced should be held to a minimum. Otherwise, situations can arise in which students just perform surface learning or strategic learning, and this, combined with motivational deficits of students, would limit their ability to engage in deeper learning processes [46]. In this study, only Belasco's food triangle [39] was introduced as an abstract theory, which explains human food decision-making as an interplay among three dimensions. It was chosen because it is a rather simple concept, which helped the students to understand the project context.

A crucial element of TD research approaches involves the integration of values from society into the research process [2]. In this regard, the students' values were discussed in eight focus group discussions and then translated into the PSS. This allowed the students to mutually explore their food consumption decisions and preferences.

When establishing a suitable project, researchers must bear in mind that the students' knowledge about certain subjects and contexts might be limited, either within the whole class, unevenly distributed among group members, or between groups. For instance, during the first research phase, the students from School A had to present the results of the food diary elicitation using simple descriptive statistics and graphical representations. While the teachers claimed that the students could work on this task without supervision, this was not the case. Therefore, the researchers needed to provide the students with additional information. In this respect, the students started the learning cycle on the first hierarchical level (i.e., knowing how to use descriptive data to create simple numeric data sets) and, with the help of a handout, applied this knowledge to the case of the food diaries (i.e., understanding). However, an evaluation of whether the students could apply their statistical knowledge to other contexts as well, which would imply a higher level of learning, was not within the scope of this research. Future research could be conducted to evaluate these levels of learning.

Another critical aspect of the case study was to maintain a participatory and cooperative learning setting that allowed all case agents to engage mutually. Three considerations helped in this regard. First, adequate research methods were chosen (i.e., photovoice and design thinking). These research methods are known to foster students' participation and motivate students to perform self-regulated learning [49-51]. Second, the RCT was established to maintain co-creation in the initial phase of the research. Third, the researchers occupied different roles regarding different issues, as is common in TD research [52]. Wittmayer and Schäpke (2014) [53] proposed a framework within which they identified the different roles: (a) reflective scientist, (b) process facilitator, (c) change agent, (d) knowledge broker, and (e) self-reflexive scientists. These roles are usually defined by the different research activities carried out and issues addressed. In this research, the researchers served as process facilitators, meaning that they did not provide fixed solutions to the problems the students encountered during their project. For instance, when the students discovered that their initial prototypes did not comply with certain specifications, the researchers led discussions on how the students could address this problem. In addition, the researchers occupied the roles of change agents and knowledge broker, while motivating the students to optimize their food products and participate in the experiments. As suggested by Roessingh and Chambers (2011) [54], the researchers and teachers encouraged the use 
of periods of reflection, self-reflection and the continuous assessment and monitoring of learning to guide the case agents through the research process.

Results of this research show that, when FTE and sustainability education are combined, Science, Technology, Engineering and Mathematics (STEM) knowledge can be integrated with sustainability knowledge and competencies. As such, this approach can be taken to educate a new brand of food engineer, "[ ... ] that thinks critically about the co-construction of public welfare and the technological system in which he or she works" [55] (p. 30). This is extremely important, because future food engineers must address new topics and dimensions such as innovation, partnerships, and social responsibility [56].

In an article about the future of sustainability science, Miller et al. (2014) [57] posed three core questions that researchers must address to promote learning for sustainable development. One of these questions, "How can research and education institutions facilitate transdisciplinary research and education and enable social learning?" [57] (p. 243), was central to this case study. A transinstitutional approach was taken in the current case study, involving two secondary schools and a university. Although real-world, PBL settings have been thoroughly integrated in SD curricula of many universities, less attention has been paid to such PBL approaches at the secondary school level. This case study provides an example of how different education institutions can facilitate research projects in a transinstitutional manner.

\section{Conclusions}

In this article, we describe the results of a study in which a PBL research approach was taken in two secondary schools. As Lehmann et al. (2008) [58] stated, PBL education in the sustainability domain needs to allow for interplay, mix, and diversity. Therefore, an open-ended research design was chosen; the students played the most active roles and the researchers and teachers acted as project facilitators and knowledge brokers. The thematic background of the case study was the development of sustainable food products for students by students. Thus, a real-world setting was established, and the students worked on their projects in three phases. The students applied participatory methods to explore their food consumption decisions and preferences (Phase 1). Subsequently, the obtained data were integrated into the food product development process using PSS (Phase 2). One limitation of the study was that the students' levels of learning (Figure 1) was not evaluated as part of this research.

One goal of the case study was to raise the students' awareness of the multiple processes and dimensions that food engineers need to consider when developing sustainable food products, such as technological, ecologic, social, and economic aspects. Here, the introduction of the PSS and the experiments helped the students optimise their products. During this process, the students found that matching different specifications simultaneously can result in conflicting situations, whereby some specifications can be mutually exclusive. Unstructured documentation of the experiments led to unreliable results, and these needed to be repeated before the results could be incorporated into the prototype optimisation process. Hence, the students engineered sustainable food products from scratch and, as they went through their product development process, engaged in iterative learning steps. Such experienced-based learning approaches are suitable for the initial development of sustainability competencies [59].

Based on the findings of this study, more scientific approaches should be established, that integrate STEM and sustainability knowledge into secondary-school subjects. These approaches should place an emphasis on the teaching systems and life-cycle thinking during the design phase of projects that involve the development of food products. In this regard, didactic concepts that bridge engineering and sustainability concepts must be chosen carefully. In summary, the case study findings illustrate that PBL research approaches can be used at different education levels to achieve positive results, if the research process is clearly structured and managed. To encourage secondary-school students to learn, teachers and university researchers need to provide additional information and resources.

Author Contributions: Conceptualization, U.S., H.D., S.B., A.P.; methodology, U.S., H.D., A.P.; investigation, H.D., U.S., D.G, S.B.; writing-original draft preparation, H.D., A.P., U.S.; writing-review and editing, H.D., 
A.P.; project administration, H.D., U.S., D.G. All authors have read and agreed to the published version of the manuscript.

Funding: This research was funded by the Federal Ministry of Education, Science and Research of Austria, Sparkling Science funding program, grant number SPA 06/078 - YoungTECHforFOOD.

Acknowledgments: The authors acknowledge the financial support by the University of Graz, which covered the open-access fees invoiced by the publisher. Furthermore, the authors express their gratitude to the Umweltdachverband, teachers of both schools, and colleagues for their great commitment to the project.

Conflicts of Interest: The authors declare no conflict of interest. The funders had no role in the design of the study; in the collection, analyses, or interpretation of data; in the writing of the manuscript, or in the decision to publish the results.

\section{References}

1. Mauser, W.; Klepper, G.; Rice, M.; Schmalzbauer, B.S.; Hackmann, H.; Leemans, R.; Moore, H. Transdisciplinary global change research: The co-creation of knowledge for sustainability. Curr. Opin. Environ. Sustain. 2013, 5, 420-431. [CrossRef]

2. Lang, D.J.; Wiek, A.; Bergmann, M.; Stauffacher, M.; Martens, P.; Moll, P.; Swilling, M.; Thomas, C.J. Transdisciplinary research in sustainability science: Practice, principles, and challenges. Sustain. Sci. 2012, 7, 25-43. [CrossRef]

3. Steiner, G.; Posch, A. Higher education for sustainability by means of transdisciplinary case studies: An innovative approach for solving complex, real-world problems. J. Clean. Prod. 2006, 14, 877-890. [CrossRef]

4. Nicolescu, B. Methodology of transdisciplinarity. World Futures 2014, 70, 186-199. [CrossRef]

5. Ramadier, T. Transdisciplinarity and its challenges: The case of urban studies. Futures 2004, 36, $423-439$. [CrossRef]

6. Scholz, R.W.; Mieg, H.A.; Oswald, J.E. Transdisciplinarity in groundwater management—towards mutual learning of science and society. Water Air Soil Pollut. 2000, 123, 477-487. [CrossRef]

7. Jahn, T.; Bergmann, M.; Keil, F. Transdisciplinarity: Between mainstreaming and marginalization. Ecol. Econ. 2012, 79, 1-10. [CrossRef]

8. Körfgen, A.; Förster, K.; Glatz, I.; Maier, S.; Becsi, B.; Meyer, A.; Kromp-Kolb, H.; Stötter, J. It's a hit! Mapping Austrian research contributions to the sustainable development goals. Sustainability 2018, 10, 3295. [CrossRef]

9. Brudermann, T.; Aschemann, R.; Füllsack, M.; Posch, A. Education for sustainable development 4.0: Lessons learned from the University of Graz, Austria. Sustainability 2019, 11, 2347. [CrossRef]

10. Brudermann, T.; Holländer, R.; Pastres, R.; Posch, A.; Schot, P. Integrating interdisciplinarity and internationality in sustainable development education. GAIA-Ecol. Perspect. Sci. Soc. 2017, 26, 360-362. [CrossRef]

11. Vermeulen, W.J.V.; Bootsma, M.C.; Tijm, M. Higher education level teaching of (master's) programmes in sustainable development: Analysis of views on prerequisites and practices based on a worldwide survey. Int. J. Sustain. Dev. World Ecol. 2014, 21, 430-448. [CrossRef]

12. Posch, A.; Steiner, G. Integrating research and teaching on innovation for sustainable development. Int. J. Sustain. High. Educ. 2006, 7, 276-292. [CrossRef]

13. Scholz, R.W.; Steiner, G. Transdisciplinarity at the crossroads. Sustain. Sci. 2015, 10, 521-526. [CrossRef]

14. Heigl, F.; Kieslinger, B.; Paul, K.T.; Uhlik, J.; Dörler, D. Opinion: Toward an international definition of citizen science. Proc. Natl. Acad. Sci. USA 2019, 116, 8089-8092. [CrossRef] [PubMed]

15. Vidgen, H.A.; Gallegos, D. Defining food literacy and its components. Appetite 2014, 76, 50-59. [CrossRef] [PubMed]

16. Nanayakkara, J.; Margerison, C.; Worsley, A. Importance of food literacy education for senior secondary school students: Food system professionals' opinions. Int. J. Health Promot. Educ. 2017, 55, $284-295$. [CrossRef]

17. Brooks, N.; Begley, A. Adolescent food literacy programmes: A review of the literature. Nutr. Diet. 2014, 71, 158-171. [CrossRef]

18. Thomas, H.M.; Irwin, J.D. Cook it up! A community-based cooking program for at-risk youth: Overview of a food literacy intervention. BMC Res. Notes 2011, 4, 495. [CrossRef] 
19. Ronto, R.; Ball, L.; Pendergast, D.; Harris, N. Adolescents' perspectives on food literacy and its impact on their dietary behaviours. Appetite 2016, 107, 549-557. [CrossRef]

20. Rutland, M.; Owen-Jackson, G. Food technology on the school curriculum in England: Is it a curriculum for the twenty-first century? Int. J. Technol. Des. Educ. 2015, 25, 467-482. [CrossRef]

21. Wickson, F.; Carew, A.L. Quality criteria and indicators for responsible research and innovation: Learning from transdisciplinarity. J. Responsible Innov. 2014, 1, 254-273. [CrossRef]

22. Scholz, R.W.; Tietje, O. Embedded Case Study Methods. Integrating Quantitative and Qualitative Knowledge; Sage Publish: Thousand Oaks, CA, USA, 2002; ISBN 0761919465.

23. Wiek, A.; Xiong, A.; Brundiers, K.; van der Leeuw, S. Integrating problem- and project-based learning into sustainability programs. Int. J. Sustain. High. Educ. 2014, 15, 431-449. [CrossRef]

24. Scholz, R.W.; Lang, D.J.; Wiek, A.; Walter, A.I.; Stauffacher, M. Transdisciplinary case studies as a means of sustainability learning. Int. J. Sustain. High. Educ. 2006, 7, 226-251. [CrossRef]

25. Stauffacher, M.; Walter, A.I.; Lang, D.J.; Wiek, A.; Scholz, R.W. Learning to research environmental problems from a functional socio-cultural constructivism perspective. Int. J. Sustain. High. Educ. 2006, 7, 252-275. [CrossRef]

26. Hansmann, R. Sustainability learning: An introduction to the concept and its motivational aspects. Sustainability 2010, 2, 2873-2897. [CrossRef]

27. Tabara, D.; Pahl-Wostl, C. Sustainability learning in natural resource use and management. Ecol. Soc. 2007, 12, 3. [CrossRef]

28. Park, J.-Y.; Son, J.-B. Transitioning toward transdisciplinary learning in a multidisciplinary environment. Int. J. Pedagog. Learn. 2010, 6, 82-93. [CrossRef]

29. Brundiers, K.; Wiek, A. Do we teach what we preach? An international comparison of problem- and project-based learning courses in sustainability. Sustainability 2013, 5, 1725-1746. [CrossRef]

30. Inchley, J.; Currie, D.; Young, T.; Samdal, O.; Torsheim, T.; Augustson, L.; Mathison, F.; Aleman-Diaz, A.; Molcho, M.; Weber, M.; et al. Growing up Unequal. Gender and Socioeconomic Differneces in Young People's Health and Well-Being: Health Behaviour in School-Aged Children (HBSC) Study: International Report from the 2013/2014 Survey; WHO: Copenhagen, Denmark, 2016; ISBN 9289051361.

31. Godfray, H.C.J.; Beddington, J.R.; Crute, I.R.; Haddad, L.; Lawrence, D.; Muir, J.F.; Pretty, J.; Robinson, S.; Thomas, S.M.; Toulmin, C. Food security: The challenge of feeding 9 billion people. Science 2010, 327, 812-818. [CrossRef]

32. Gerbic, P.; Maher, M. Collaborative self-study supporting new technology: The Mahara e-portfolio project. In Proceedings of the 25th Annual Conference of the Australasian Society for Computers in Learning in Tertiary Education; Deakin University, Deakin, Australia, 8-9 May 2008.

33. Walter, A.I.; Helgenberger, S.; Wiek, A.; Scholz, R.W. Measuring societal effects of transdisciplinary research projects: Design and application of an evaluation method. Eval. Program. Plan. 2007, 30, 325-338. [CrossRef]

34. Binder, C.R.; Absenger-Helmli, I.; Schilling, T. The reality of transdisciplinarity: A framework-based self-reflection from science and practice leaders. Sustain. Sci. 2015, 10, 545-562. [CrossRef] [PubMed]

35. Carew, A.L.; Wickson, F. The TD Wheel: A heuristic to shape, support and evaluate transdisciplinary research. Futures 2010, 42, 1146-1155. [CrossRef]

36. Dym, C.L.; Agogino, A.M.; Eris, O.; Frey, D.D.; Leifer, L.J. Engineering design thinking, teaching, and learning. J. Eng. Educ. 2005, 94, 103-120. [CrossRef]

37. Olsen, N.V. Design thinking and food innovation. Trends Food Sci. Technol. 2015, 41, 182-187. [CrossRef]

38. Brown, T.; Wyatt, J. Design thinking for social innovation. Dev. Outreach 2010, 12, 29-43. [CrossRef]

39. Belasco, W.J. Food. The Key Concepts; Berg: Oxford, UK, 2008; ISBN 978-1-84520-672-7.

40. Roberts, C.; Freeman, J.; Samdal, O.; Schnohr, C.W.; de Looze, M.E.; Nic Gabhainn, S.; Iannotti, R.; Rasmussen, M.; The International HBSC Study Group. The health behaviour in school-aged children (HBSC) study: Methodological developments and current tensions. Int. J. Public Health 2009, 54, 140-150. [CrossRef]

41. Wang, C.; Burris, M.A. Photovoice: Concept, methodology, and use for participatory needs assessment. Health Educ. Behav. 1997, 24, 369-387. [CrossRef]

42. Strack, R.W.; Magill, C.; McDonagh, K. Engaging youth through photovoice. Health Promot. Pract. 2004, 5, 49-58. [CrossRef] 
43. Harper, K.; Sands, C.; Angarita Horowitz, D.; Totman, M.; Maitín, M.; Rosado, J.S.; Colon, J.; Alger, N. Food justice youth development: Using Photovoice to study urban school food systems. Local Environ. 2017, 22, 791-808. [CrossRef]

44. Tonkinwise, C. A taste for practices: Unrepressing style in design thinking. Des. Stud. 2011, 32, 533-545. [CrossRef]

45. Wills, W.J. Using spoken and written qualitative methods to explore children's and young people's food and eating practices. Sociol. Res. Online 2012, 17, 1-10. [CrossRef]

46. Warburton, K. Deep learning and education for sustainability. Int. J. Sustain. High. Educ. 2003, 4, 44-56. [CrossRef]

47. Maher, J.; Burkhart, S. Experiential learning for engaging nutrition undergraduates with sustainability. Int. J. Sus High. Ed. 2017, 18, 1108-1122. [CrossRef]

48. Brunetti, A.J.; Petrell, R.J.; Sawada, B. SEEDing sustainability. Int. J. Sustain. High. Educ. 2003, 4, $210-217$. [CrossRef]

49. Tu, J.-C.; Liu, L.-X.; Wu, K.-Y. Study on the learning effectiveness of Stanford design thinking in integrated design education. Sustainability 2018, 10, 2649. [CrossRef]

50. Sheehan, N.T.; Gujarathi, M.R.; Jones, J.C.; Phillips, F. Using design thinking to write and publish novel teaching cases: Tips from experienced case authors. J. Manag. Educ. 2018, 42, 135-160. [CrossRef]

51. Spencer, R.A.; McIsaac, J.-L.D.; Stewart, M.; Brushett, S.; Kirk, S.F.L. Food in focus: youth exploring food in schools using photovoice. J. Nutr. Educ. Behav. 2019, 51, 1011-1019. [CrossRef]

52. Pohl, C.; Rist, S.; Zimmermann, A.; Fry, P.; Gurung, G.S.; Schneider, F.; Speranza, C.I.; Kiteme, B.; Boillat, S.; Serrano, E.; et al. Researchers' roles in knowledge co-production: Experience from sustainability research in Kenya, Switzerland, Bolivia and Nepal. Sci. Pub. Political 2010, 37, 267-281. [CrossRef]

53. Wittmayer, J.M.; Schäpke, N. Action, research and participation: Roles of researchers in sustainability transitions. Sustain. Sci. 2014, 9, 483-496. [CrossRef]

54. Roessingh, H.; Chambers, W. Project-based learning and pedagogy in teacher preparation: Staking out the theoretical mid-ground. Int. J. Teach. Learn. High. Educ. 2011, 23, 60-71.

55. Tejedor, G.; Segalàs, J.; Rosas-Casals, M. Transdisciplinarity in higher education for sustainability: How discourses are approached in engineering education. J. Clean. Prod. 2018, 175, 29-37. [CrossRef]

56. Saguy, I.S. Challenges and opportunities in food engineering: Modeling, virtualization, open innovation and social responsibility. J. Food Eng. 2016, 176, 2-8. [CrossRef]

57. Miller, T.R.; Wiek, A.; Sarewitz, D.; Robinson, J.; Olsson, L.; Kriebel, D.; Loorbach, D. The future of sustainability science: A solutions-oriented research agenda. Sustain. Sci. 2014, 9, 239-246. [CrossRef]

58. Lehmann, M.; Christensen, P.; Du, X.; Thrane, M. Problem-oriented and project-based learning (POPBL) as an innovative learning strategy for sustainable development in engineering education. Eur. J. Eng. Educ. 2008, 33, 283-295. [CrossRef]

59. Caniglia, G.; John, B.; Kohler, M.; Bellina, L.; Wiek, A.; Rojas, C.; Laubichler, M.D.; Lang, D. An experience-based learning framework. Int. J. Sustain. High. Educ. 2016, 17, 827-852. [CrossRef]

(C) 2019 by the authors. Licensee MDPI, Basel, Switzerland. This article is an open access article distributed under the terms and conditions of the Creative Commons Attribution (CC BY) license (http://creativecommons.org/licenses/by/4.0/). 